\title{
Sustainable Housing Development and Functionality of Planning Laws in Nigeria: the Case of Cosmopolitan Lagos
}

\author{
Dr. Ola Aluko \\ Dept. of Urban \& Regional Planning \\ Faculty of Environmental Sciences \\ University of Lagos, Akoka, Lagos, Nigeria
}

Tel: 234-80-2324-0693 E-mail: eoaluko@yahoo.com

Received: May 26, 2011

Accepted: August 4, 2011

doi:10.5539/jsd.v4n5p139

\begin{abstract}
The phenomenal growth of our towns and cities has given rise to conurbation and metropolitan areas, with various planning problems such as traffic congestion, slum, shanty towns, waste management, housing, pollution, poverty and several others. There is no doubt that the impact of rapid population growth on housing development in a developing economy is usually a consequence of the push of the rural areas and the pull of the town. There is always an upsurge and conglomeration of people in city centres with the resultant effects on housing growth arising from acute unemployment. This growth and physical expansion of cities have been accompanied by unplanned urban sprawl, environmental pollution, deterioration, deficiencies in modern basic facilities, and general urban decay. As increased poverty and urbanization exert more pressures on urban facilities, most Nigerian cities tend to have lost their original dignity, social cohesion and administrative efficiency. Land Administration in Lagos State, over the last 25 years cannot be described as being sustainable. Though, various tools might have been put in place concerning the administration of land, there are still a whole lot of problems being faced on and matters in the state.

Planning for housing and setting standards for the regulation of building construction is a task that seems to overwhelm the relevant government authorities in Nigeria and other parts of the developing world. This paper therefore examines the planning laws and ordinances available in Nigeria, with specific reference to the new Lagos State Urban and Regional Planning and Development Law 2010, the types and levels of the Planning Authorities and Agencies responsible for the implementation of the laws. It also appraises their activities so far in the area of implementation, their challenges and lastly, makes recommendation for improvement.
\end{abstract}

Keywords: Sustainability, Planning laws, Housing development

\section{Introduction}

However, the phenomenal rate of urbanization and subsequent increased demand for the use of land both in the cities and rural areas for physical development in Nigeria has been on the increase since the 1970s. In the face of these problems confronting government in meeting the demand and desires of the public, government had to be responsible in ensuring that land is adequately provided and development controlled for the overall benefit of the public. This process is called land administration. Today, land tenure in Nigeria is governed by the Land Use Act of 1978 under which all land in all the states of federation is vested in the Governor. Access to land is by way of a 'right of occupancy' granted by the government. This development had led to a lot of controversies in the acquisition, disposal, use and administration of land both in the rural and urban areas. More disturbing is the implication of this form of ownership for land development, housing provision and access to decent living

Though, various studies have made substantial contributions to land administration in Nigeria, most of them have not been able to fill the loopholes that exist in the method of administration of land, particularly in Lagos State and how it affects the physical development. None of the studies have been able to fully explain the implication of the method of land administration adopted in the state on sustainable development. Concentration of various studies on land administration has been on the criticism of the Land Use Act and its implication on physical planning. It should be noted however, that sustainable development requires a sound land administration system. Sustainable Development does not focus solely on economic issues. More broadly, sustainable development policies encompass three general policy areas: economic, environmental and social. In essence, there is need to examine the method of land administration adopted in Lagos and the implication it has on physical development. 


\section{Research Problem}

Land Administration in Lagos State, over the last 25years cannot be described as being sustainable. Though, various tools might have been put in place concerning the administration of land, there are still a whole lot of problems being faced on and matters in the state. Subject to the Land Use Act S. 1 of 1978 which states that "all land comprised in the territory of each state in the federation are hereby vested in the State Governor of that state and such land shall be held in trust and administered for the use and common benefit of all Nigerians in accordance with the provision of this Act", administration of land in each state of the federation is supposed to be easier and better for the benefit of all Lagosians but 32years after the promulgation of this act, this aim is far from being achieved. Vesting of land in State Governors has created powerful systems of authority and political patronage. The question now is whether the land tenure system adopted in the state actually ensures the availability of land to all and sundry like it claims, whether people have access to land the way they should and the overall effect of this system on sustainable housing development.

\section{Planning Laws and Ordinances, Administration, Execution and Implementation in Nigeria}

\subsection{Lagos State Urban and Regional Planning and Development Law}

The additional administrative machinery from the new law states that The Ministry shall be responsible for the(a) initiation, formulation of Policies, coordination of programmes and review of all aspects of Physical Planning, Urban Development, Urban Regeneration and Building Control in the State;

(b) Implementation of its policies through the relevant agencies established under the provisions of this Law;

(c) preparation and approval of the following hierarchies of Physical Development Plans:

(i) Regional Plans;

(ii) Sub-Regional Plans;

(iii) District Plans;

(iv) Model City Plans;

(v) Urban/Town Plans;

(vi) Urban Regeneration Plans;

(vii) Development Guide Plans; and

(viii)Local Plans including layout and subdivision plans;

(d) provision of technical assistance to all government ministries and agencies on matters relating to physical planning, urban development, urban regeneration and building control;

(e) determination of the locations of infrastructural facilities and centres of economic activities in the State;

(f) offering advice on State development projects/programmes with socio-economic and environmental impacts as may be referred to it from time to time;

(g) formulation of legislations on physical planning, urban development, urban regeneration and building control in the State;

(h) formulation of guidelines for fostering inter-ministerial, intergovernmental,

bilateral and multi-lateral cooperation on physical planning, urban development, urban regeneration and building control;

Part III Section 47 states that The Building Control Agency shall be responsible for the:

(a) enforcement of building control regulations;

(b) regulation and inspection of building works and, certification of various stages of building construction and keeping of such records;

(c) removal of illegal and non-conforming buildings;

(d) identification and removal of distressed buildings to prevent collapse;

(e) issuance of Certificate of Completion and Fitness for Habitation;

(f) provision of building services such as material evaluation and testing, fire and public health control; 
(g) establishing Local Building Control Offices in cooperation with the Local Governments and Local Council Development Areas for the discharge of its functions at the Local Government level with the approval of the Governor on the recommendation of the Commissioner;

\subsection{The Land Use Act (chapter 202 of the Laws of Nigeria 1990) and Physical Planning}

The Preamble of the Act leads to the background of the Act. It states that "It is in the public interest that the rights of all Nigerians to the land of Nigeria be asserted and preserved by Law .... the rights of all Nigerians to use and enjoy land in Nigeria and the natural fruits thereof in sufficient quantity to enable them provide for the sustenance of themselves and their families should be assured, protected and preserved( Cap 202, 1978).

It is An Act to Vest all Land compromised in the territory of each State (except land vested in the Federal government or its agencies) solely in the Governor of the State, who would hold such Land in trust for the people and would henceforth be responsible for allocation of land in all urban areas to individuals resident in the State and to organizations for residential, agriculture, commercial and other purposes while similar powers will with respect to non urban areas are conferred on Local Governments (27 $7^{\text {th }}$ March 1978) Commencement.

With reference to physical planning there are two major areas of the Act that are of interest, they are the ownership of the Land and secondly the categorization of localities into urban and rural areas for effective development control.

\subsection{Urban and Regional Planning Decree 88 of 1992}

The Nigeria Urban and Regional Planning (Decree No. 88, 1992) is the long awaited Planning law expected to guide orderly physical development in modern Nigeria. The birth of the Decree was preceded by forty - six year of outdated Town and Country Planning Law of 1946. The new law is thus expected to reinvigorate the dull and static Planning activities pervading the post independent physical development in Nigeria. Most, if not all section are therefore expected to be contemporary, new or least fit closely well with exiting planning issues in the country, land acquisition, disposal, transfer and so forth are some of the issues expected to be central in the new planning law. The new 2010 Lags State Law have taken cognisance of all the existing laws and modernise it to suit the peculiar situation of Lagos State. Lagos State has the smallest size of land in Nigeria compared to its huge population size.

All land and related issues in the Decree are referred to the Land Use Act. Some relevant sections in the Decree in this context are:

i. Conditions for grant of development permit by a Development Control Department (DCD) must conform to condition of issue of Certificate of Occupancy or a customary right of occupancy as provided for the Act (s. 36 . Degree No. 88 of 1992). See also Part II sections 24-41 of the 2010 Lagos State Law.

ii. The development Control Department in approving and rejecting a Development permission as provided for under section 34 of the Decree is to take into account matters of overriding public interest (s. 43 (2)(a) of the Decree). This is contained in Part III sections 45-48 of the 2010 Lagos State Law.

iii. Condition for compensation for revocation would only be if the application had complied with the requirement of the Act with respect to right of occupancy of the land on which a development was to take place (s. 43(2)(b) of the Decree No. 88, 1992). Contained in sections $42-44$ and 77 of the 2010 Lagos State Law.

iv. The commission Board, or Authority (s. 5(a)(b)(c) of the Decree) responsible for physical planning at the federal, state and local government level respectively are empowered to revoke acquired occupancy to obtain any land in connection with approved urban or rural development plan. However such revocation must be in accordance with the relevant provisions of the Act (s. 75(2) of the Decree). This is also taken care by section 2(m) of the 2010 Lagos State Law.

v. All matter connected with the payment of compensation for the revocation of right of occupancy under part IV (Acquisition of land and Compensation) of the Decree are to be governed in accordance with the relevant provisions of the Act (s. 76(1) of the Decree).

vi. Urban area is defined in the Decree (s. 91) according to the definition in section 3 of the Act. See sections 42 and 77 of 2010 Lagos State Law.

The foregoing shows one discernible scenario: that is since development, of any form, takes place on the land, compliance with virtually all provisions of the Decree rests on the Act. The implication of this is obvious. Successful implementation of the contemporary planning legislation in Nigeria still depends on the workability of the controversial Land Use Act. 


\section{Housing Delivery in Lagos}

When we examine the housing delivery system, we tried to explain the total number of building constructions that is made available especially to the people and rental sub sector. Tables $1-7$ give the statistics showing the number of certificates of occupancy received, processed, approved and collected between 2000 and 2006. Certificates of occupancy are collected on land to be developed for building purposes. The assumption is that the number of housing development can be estimated from the legal document. When we compare the figures of the buildings that are finally ratified and collected with number of submissions for processing and approved, we found out that they are very low. Which indicates that rate of building construction is very low compared with expected demand from households. The minister for works and housing admitted when he said "the ministry is aware of the huge housing problems facing the people" (The Liberation, May 25, 2011, p.4). The ministry has requested for N5.5 trillion (\$3.6 billion) from the Federal Mortgage Bank of Nigeria (FMBN) and National Housing Fund (NHF) to build 20 million housing units across the country. So with millions of housing units needed in Lagos alone, hardly can the State boast of 5000 housing supply annually.

\section{Problems of Land Administration in Lagos State Problems Usually Encountered While Processing Governor's Consent}

Over the years, we have identified problems that have stalled and in some instances prevented applicants from obtaining Governor's Consent. The following are some of the problems usually encountered.

i. Incomplete documentation: With the zeal to impress their clients, some agents submit applications that were not accompanied by documents such as Certified True Copy of the Root of Title; genuine survey plan and duly signed / attested Form $1 \mathrm{c}$.

ii. Irregular signature: There were also cases where the signatures of parties to the transaction were found to be irregular. It was usually assumed that the signature might have been forged. In such circumstances, the processing of the file is put on hold and a thorough investigation undertaken and this could take a while.

iii. Non-Compliance with Survey Edict

a.In some cases applicants bring in Survey plans that do not correspond with the subject matter of the transaction e.g. bringing survey plan for property ' $\mathrm{A}$ ' while property ' 8 ' is the property that is supposed to be mortgaged or assigned.

b.Non submission of Record copy at the Office of the Surveyor General.

c.Not stamping or indicating that the land is free from Government revocation / acquisition.

d.Flying of coordinates, i.e. using the coordinates for a land that is in an area deemed' as being free from Government revocation/acquisition for a land in an area that is under revocation / acquisition.

iv. Payment of inadequate tax or submitting fake tax clearance certificate

v. Non discharge of Cautions/encumbrance:

Cautions/encumbrance subsisting on property to be transferred cannot be processed further until the caution has been discharged.

vi. Bad legal drafting: The examples of include omitting to frank the deeds, having conflicting information on the deeds and Form $1 \mathrm{C}$ and placing the endorsement, column on the wrong page of the deed.

vii. Inconsistency in documents submitted for processing.

viii. Defect in Root of Title

a.Previously unperfected title.

b.Not submitting letter of administration or grant of probate when dealing with a deceased estate.

c.Inability to establish relationship between the grantor and the root of title to the' property.

ix. Failure/omitting to pay consent fees: In many cases applicants abandon transactions after a demand notice is issued for payment of the balance of consent fees. In such circumstances, the office is unable to process the file further until the balance payment is made.

x.Incorrect contact details: In some cases, applicants failed to give proper address or contact details in the file. Consequently, it sometimes becomes impossible to contact such applicants should the need arise.

In the situations enumerated above, the files are sent to the strong room for safe keeping pending when the applicants would have rectified the problems. 


\subsection{Problems Encountered Within Government Agencies}

It has been observed that doing business with government can be cumbersome, complex and tiring with endless to and fro, unending paper work and limited time out. This is not without the usual public corruption quagmire, favorism, nepotism and abuse of office by concerned public officer.

It is well borne out by experience that in addition to the prescribed statutory fees and prescribed transaction cost, securing service from a government agency more often than not, entails any or all of the following indirect cost.

-Delay and uncertainty

-Lack of transparency

-Corruption

-Mistrust/ill-treatment at the offices

-Loss of wages/productivity of the citizen/business

- Cost of travel and stay at the place of services

\subsection{Problems With The Land Use Act Which Affect Land Administration}

Though the Land Use Act, 1978 is necessary for regulating the acquisition and use of land because of the great importance of land in socioeconomic development, it has created more problems than it seek to solve in its current form. Land Use Act was conceived with noble objectives, but the implementation of the law over the years has created more problems and iniquities in land administration in this country than the problems it was designed to address. The problems created by the implementation of the Act are largely due to the provisions of the Act were based on the wrong assumptions that the interest of the people in relation to land in this country are the same and that the Governor as a trustee will always act in the best interest of the people all the time.

Some aspects of the law have hampered the socio-economic development of the country and make land inaccessible to the people, thereby defeating its main objective of making land for development available to all. The Act altered existing land laws, particularly in Southern Nigerian in three critical ways, by first removing families and chiefs as trustees of land and replacing them with the state Governor. secondly, he noted, individual interest in land had been reduced to a mere right of occupancy; while land in rural areas were placed under the control of the local governments; with individuals no longer enjoying right of ownership over land.

The idea of the Governor holding land in trust for the people is totally misconceived as it has not adequately benefited the people especially the land owning families and communities. Many state Governors had converted the consent provision to cash cows through the imposition of several levies on consent applications, while a lot of administrative bottlenecks had been created in the procedure for obtaining consent; all of which had resulted in undue delays $m$ completing land transactions and payment of hefty sums.

The valuation of the land is done by government officials who usually ignore the consideration in the Deed of Assignment and impose their own valuation. If the intention of the consent provision is to ensure that all transactions in land comply with the provisions of the Act, its operations in practice have defeated the objective of making and readily available $\mathrm{b}$ adding enormously to the cost of land transactions. On the worth of the Certificate-of-Occupancy, Section 9 of the Act empowered the Governor to issue the document to evidence right of occupancy upon payment of prescribed fee. Deed of Conveyance, which is a title to land, the C-.of-O issued under the Act did not confer any title as it was a mere evidence of it; noting that though it was a mere evidence of title, failure to pay for it was one of the grounds upon which the Governor could revoke the right of occupancy. One of the problems associated with the C-of-O is that it does not transfer any interest in land.

\section{Sustainable Development}

The term sustainable development has been defined as 'development that meets the needs and aspirations of the current generations without compromising the ability to meet those of future generations. In a more general way, the concept of sustainable development may be seen as the facilitator for balancing the conservation of nature's resource with the needs for development. That is, sustainable development means improving the quality of human life while living within the carrying capacity of supporting ecosystems. The field of sustainable development can be conceptually broken into three constituent parts: environmental sustainability, economic sustainability and social-political sustainability. Sustainable development does not focus solely on environmental issues. More broadly, sustainable development policies encompass three general policy areas: economic, environmental and social. In support of this, several United Nations texts especially the 2005 World Summit Outcome document, refer to the "interdependent and mutually reinforcing pillars" of sustainable development as economic, social 
development and environmental protection. Nigeria is committed to a national policy on the environment that ensures sustainable housing development based on proper management of her natural resources in a manner, which meets the needs of the present and future generations. This requires balancing her human needs against the potential that the environment has for meeting them. The Nigerian policy, which identifies the correlation between the health and welfare of all Nigerians, and the urgent transition to sustainable housing development, attempts to provide the concepts and strategies that will lead to the procedures and other concrete actions required for launching Nigeria into an era of social justice, self reliance, and resource development that are environmentally friendly. But with the level of poverty among the people sustaining the housing development will remain a herculean tasks.

\section{Development Control}

Development is therefore seen as a restoration of free will placed on any developer of any property. Thus, any change in the use of any planning agency as recognized by the law. It can be further defined (development control) as the process and procedures concerned with controlling the development of land and building. It is the practice of regulating, restraining, keeping in order or checking changes on land use that are in conflict with the wish of a developer and the benefit to the public. In line with the definition of development, development control actually regulates any building or rebuilding operation in, on and under the land. It also ensures an order growth of settlement by stipulating adequate standards for all aspects of land use through the provision of adequate lighting, ventilation, opening spaces and all other $b$ socio-cultural facilities that make life worth living in line with the overall plan of the area concerned. This power to grant or refuse or attach conditions to permission for development to take place gives the public planning agencies the big teeth.

Through development control activities of planning agencies, (see section 38 and all sections in Part V of 2010 Lagos State Law), the planning laws and regulations are enforced. The extent and level of enforcement, however, depend on the nature and contents of the laws and regulations, public understand of the perception of the laws, competence of the enforcement officers and availability of manpower to ensure that any form of development as defined conforms to the approved guidelines and registrations.

\subsection{Development Control and Planning Regulations}

Control of development (see section 45-48 of the 2010 Lagos State Law) in any form in urban and rural areas is deeply rooted in the development process of the built environment in the country. Before the advent of colonial administration in the country, the traditional rules in the different regions controlled development according to the traditional ways of environment control measures. There were no specific written regulations as such but every form of development was in line with the approval of the family first, and the community at large through the traditional rulers under the Nigeria customary law. Control of development was historically based on native law and custom and was legal, since customary law is law.

Through the rate of physical development was relatively low and the pattern was also rudimentary, it was evident that there were some measures of control of physical development what is still clear, however, going by the pattern of layouts and growth of many traditional cities and rural areas is that physical development before colonial rule was allowed without much restriction and co ordination resulting in amorphous growth. The absence of a development plan of any type in many areas of the country as well as traditional way of ownership of land could have been responsible for this situation.

The first ever known form of development control measure in the country was through the 1863 Town improvement Ordinance of Lagos. Other town and country planning legislation before 1946 had similar orientation in control of development in the sense that they restricted enforcement of modern planning regulations as it were to just Lagos city area and more importantly, to the Government Reservation Areas (GRAs). In fact the Brazilian quarters of the Lagos City Island still retain its pre-colonial pattern till date. The 1928 Town Panning Ordinance only ameliorates the situation of haphazard development with the establishment of the Lagos Executive Development Board (LEDB). The LEDB through the ordinance was much concerned with slum clearance in Lagos Island and housing schemes in Surulere, Ikoyi, Apapa and industrial layouts at Ijora and Iganmu Development control activity of a federal planning agency like LEDB was completely absent.

The 1946 Ordinance not only empowers the government to establish local planning authorities but also explicitly made development control the main activity of the authorities. The Ordinance specifically prohibited carrying out of development without adequate planning permission from the planning authority. The scope of development control measures as contained in the 1946 ordinance is what is still widely practiced by public planning authorities in the country till date. However, between 1946 and 1992 there were several legislation relating to development control in form of building regulations building adoptive by-laws public health law and so on that had been 
enacted. Many of these building adoptive by-laws (i.e. the former Western State of Nigeria by-laws of 1960, No. 171 of 1960) made provision for air space, building lines density control and so on and are still in use till present time.

\subsection{Building Line or Setback}

The Building Line or Setback refers to the distance from the front, back, or side of a lot beyond which construction or improvements may not extend without permission by the proper governmental authority or other party. The building line may be established by a filed plat of subdivision, by restrictive covenants in deeds, by building codes, or by zoning ordinances. The building by-laws also referred to as subdivision regulation by the built environment professionals, deserve further discussion. Part I, Section 12 of the First Schedule 2010 Law deals with the Regulations and Standards on setback. It includes Comprehensive Development Plans shall include regulations and standards which define the scope and limits within which District Plans and other Development Plans are to be framed and drafted. These shall include the following:

12(1)(b) formation, minimum requirements for dwelling units of various types including sizes, service cores, room sizes, ceiling height and day lighting or ventilations;

(c) Building site requirements and limitations, minimum building lines, airspaces, and maximum coverages, height and plot ratios, for the main types of residential, commercial, industrial and institutional developments in defined use zones.

\section{Methodology for Measuring The Functionality of the Town Planning Authorities in Effecting Urban and Regional Planning Laws and Control in Lagos State}

Functionality is the measure of the usefulness, effectiveness and efficiency of a factor in achieving what it is meant for. The functionality of the town planning agencies can be measured using the Environmental Planning Management (EPM) Process. The EPM process is rightly described as a the steps needed to carry out and implement environment management plans for the purpose of ensuring that achievements in social, economic and physical development last for the benefit of the present and future generations.

According to the UNCHS 1996, it is an articulated analytical framework and logical structure which facilitates better understanding of the dynamism of urban development and environmental issues and helps in evolving convincing guidelines or strategies for intervention. The EPM process is made up of both the descriptive (analytical) and prescriptive (normative) mechanisms for responsive urban management. The analytical framework of the process provides vigorous examination of the actual process of urban and environmental development, while the prescriptive framework provides guidelines for decision making and action for improving the process of urban environmental planning and $m$ management.

The EPM is designed to achieve the followings

I. To identify urban environmental issues before they become uncontrollable and too expensive to deal with.

II. To agree to strategies and actions to resolve identified environmental issue among all those whose cooperation is required.

III. To implement strategies through coordinated public and private actions.

\subsection{Justification for using the EPM}

The fact that the EPM has the frame work of the description of urban problem and also the prescriptive frame work for the solution makes it a good measurement process for the functionality of the planning agencies. The Planning Agencies have identified problematic areas and they are prescribed Law and ordinances to control then, so as to avoid chaotic and uncontrollability. Through the EPM also the strategies arrived at which are the ordinances could be implemented coordinated public and private actions.

\subsubsection{The planning Authorities' efforts in the study Area}

Planning Agencies and Authorities in the State have tried in many ways to achieve a perfect environment.

- $\quad$ Making master plans for the states and cities (done by the state for the LPA)

- $\quad$ Zoning Land uses (There are now areas strictly for commercial Purposes and the roads and rail way lines are now free of street trader making clearer access for road user. Commuter buses now have their own garages not as when the park haphazardly before State Government Intervention)

- $\quad$ Providing planning Schemes( Housing Estates, also done by the state for LGA) examples of which are LSDPC, DAIRY FARM ESTATES 
- Creation of circulation routes, with collaborative efforts of relevant agencies

- Formulation of policies that can solve infrastructural deficiency problems

- Carrying out urban regeneration to stop the issues of slums and blight areas

- $\quad$ Making laws and order

- $\quad$ Doing many more.

8.1.2 Areas that still requires attention

Despite these efforts, a lot of settlements in the study are still experience flooding which is as result of blocked drainages example of which is Oke-koto area where the capitol road collects and empties vehicles to Pen cinema and lyana Ipaja road, though restructuring work is on is progress on the Capitol road as the time of writing this paper. Urban slums, street trading and so on are still in some core area of Old Oko Oba, and Olabua section of the Orile road (see pictures at the appendix).

However planning Authorities have been limited to the physical environment in times past, but nowadays they find themselves as key agents in solving the holistic environmental issues. Government has created policies and bodies that will assist the planning Agencies in place like Lagos. They have the Environmental Protection Agencies, The Lagos state waste Management Authorities, the Lagos state road maintenance authorities, the water from management authorities, the tourism boards, The Kick against indiscipline (KAI) task forces and more, so as to achieve a perfect environment.

A magical event occurred in a place called Oshodi in Lagos state of recent, anyone familiar with that area will know the place that as at two years ago to be a place of business agglomeration, evidently filled with features of urban decay, homes for hoodlums and pick pockets, little space for vehicular and human traffic. It was a place of lawlessness.

Today the place has been transformed from one of the dirtiest places on earth to one of the neatest places on earth. The Laws and ordinances for the right of way, environmental and public health were there before the area became an eyesore, but their implementation using all agencies, though it was forceful achieved the great results.

\section{Conclusion and Recommendations}

It is observed that Planning Authorities alone cannot enforce all the planning ordinances and laws that are to be implemented to achieve a desirable environment. It is therefore important for planning authorities to seek for team work and collaboration with other relevant fields in order to enhance capacity building to improve functionality.

- Planners and planning agencies often dabbles and double up into filling the gap other professions such as transportation and landscape design making the task almost burdensome or doing thing haphazardly. In the light of this planning Authorities should involve and employ other land related professionals

- Planning Authorities should also have members of the Executive arm of government working with monitoring sections of the planning Agencies that will make quick arrest of environmental law offences examples of which are the sanitary inspector and Special Forces that kick against in indiscipline.

- Planning Agencies should also be loyal to duty avoiding kick whatever form it may appear.

\section{References}

Akimoladun O.I (1998) Roles and Status of Town/Urban Panning in the Environment. The Lagos Journal of Environmental Studies, pp, 125-128

Aluko, O. (2000). Development Control and Nigeria's New Civil Rule Programme. NITP pp. $79-88$.

Ephraim C. and Nhamo M. (2011) Adaption and Mitigation Strategies in Sustainable Land Management, Journal of Sustainable development in Africa, Clarion University Pennsylvania, Vol. 13 No. 2, pp. 67-75.

Falade Bade (1992) The Professional Planner and scope of planning Scope Service in the light of decree 88 of 1992.

Kayode Oyesiku (1998) Modern Urban and Regional Planning Law and Administration in Nigeria

Messay M. Tefera (2011) Land Use/ Land Cover Changes in Ethiopia: A Case Study from Nouno District, Central Ethiopia, Journal of Sustainable development in Africa, Clarion University Pennsylvania, Vol. 13 No. 1, pp. 123-145.

State Land Bureau (2007) The Process of Land Ownership in Lagos.Lagos State: Printing Corporation 
Lagos State Ministry of Finance (2008) The annual remittance by agencies and department. Lagos State Printing Corporation.

Lagos State Ministry of Lands (2007) Land allocation in Lagos State. Lagos State Printing Corporation.

Lagos State (2010) Urban and Regional Planning and Development Law.

Statistics showing the number of certificate of occupancey received, processed, approved and collected 2000-2006

Table 1. Monthly number of $\mathrm{c}$ of o received, processed, approved and collected: 2000

\begin{tabular}{|l|l|l|l|l|l|l|l|l|l|}
\hline \multicolumn{9}{|l|}{ Number of certificate of occupancy (C.of O) } \\
\hline & Received for processing & \multicolumn{2}{l|}{ Approved } \\
\hline Month & $\begin{array}{l}\text { States } \\
\text { land }\end{array}$ & Ratification & $\begin{array}{l}\text { Private } \\
\text { land }\end{array}$ & $\begin{array}{l}\text { State } \\
\text { land }\end{array}$ & ratification & $\begin{array}{l}\text { Private } \\
\text { land }\end{array}$ & $\begin{array}{l}\text { State } \\
\text { land }\end{array}$ & ratification & $\begin{array}{l}\text { Private } \\
\text { land }\end{array}$ \\
\hline Jan & 150 & 32 & 44 & & 40 & 102 & & 32 & 22 \\
\hline Feb & 225 & 45 & 50 & & 210 & 250 & & 20 & 40 \\
\hline Mar. & 219 & 41 & 58 & & 360 & 275 & & 10 & 30 \\
\hline Apr. & 189 & 33 & 41 & & 360 & 275 & & 50 & 20 \\
\hline May. & 220 & 35 & 49 & & .402 & 383 & & 20 & 80 \\
\hline Jun. & 106 & 17 & 22 & & 480 & 420 & & 48 & 60 \\
\hline Jul. & 152 & 32 & 34 & & 590 & 540 & & 28 & 40 \\
\hline Aug. & 192 & 56 & 80 & & 620 & 600 & & 68 & 35 \\
\hline Sept. & 221 & 42 & 62 & & 650 & 720 & & 35 & 60 \\
\hline Oct. & 180 & 51 & 58 & & 680 & 725 & & 45 & 55 \\
\hline Nov. & 123 & 43 & 49 & & 730 & 850 & & 25 & 35 \\
\hline Dec. & 58 & 60 & 65 & & 750 & 870 & & 2 & 54 \\
\hline Total & $\mathbf{2 0 3 5}$ & $\mathbf{4 8 7}$ & $\mathbf{6 1 2}$ & $\mathbf{0}$ & $\mathbf{5 8 7 2}$ & $\mathbf{6 0 1 0}$ & $\mathbf{0}$ & $\mathbf{3 8 3}$ & $\mathbf{5 3 1}$ \\
\hline
\end{tabular}

Table 2. cotnd. Monthly Number of C of O Received, processed, Approved and Collected: 2001

\begin{tabular}{|l|l|l|l|l|l|l|l|l|l|}
\hline \multicolumn{9}{|l|}{ Number of certificate of occupancy (C.of O) } \\
\hline & Received for processing & \multicolumn{2}{l|}{ Approved } & \multicolumn{2}{l|}{ Collected } \\
\hline Month & $\begin{array}{l}\text { States } \\
\text { land }\end{array}$ & Ratification & $\begin{array}{l}\text { Private } \\
\text { land }\end{array}$ & $\begin{array}{l}\text { State } \\
\text { land }\end{array}$ & ratification & $\begin{array}{l}\text { Private } \\
\text { land }\end{array}$ & $\begin{array}{l}\text { State } \\
\text { land }\end{array}$ & ratification & $\begin{array}{l}\text { Private } \\
\text { land }\end{array}$ \\
\hline Jan & 211 & 40 & 62 & & $\mathbf{5 8}$ & 126 & & 14 & 124 \\
\hline Feb & 213 & 42 & 63 & & $\mathbf{1 6}$ & 69 & & 34 & 117 \\
\hline Mar. & 302 & 35 & 82 & & 16 & 26 & & 36 & 80 \\
\hline Apr. & 216 & 26 & 66 & & 15 & 42 & & 26 & 55 \\
\hline May. & 388 & 67 & 105 & & 34 & 82 & & 36 & 58 \\
\hline Jun. & 430 & 52 & 93 & & 44 & 97 & & 4 & 67 \\
\hline Jul. & 811 & 64 & 86 & & 54 & 20 & & 27 & 51 \\
\hline Aug. & 1026 & 66 & 100 & & 20 & 54 & & 29 & 73 \\
\hline Sept. & 1121 & 72 & 74 & & 18 & 88 & & 4 & 22 \\
\hline Oct. & 469 & 78 & 97 & & 57 & 95 & & & \\
\hline Nov. & 485 & 66 & 94 & & & & & 60 & 112 \\
\hline Dec. & 345 & 78 & 85 & & 15 & 49 & & 34 & 61 \\
\hline Total & $\mathbf{6 0 1 7}$ & $\mathbf{6 8 6}$ & $\mathbf{1 0 0 7}$ & $\mathbf{0}$ & $\mathbf{3 4 7}$ & $\mathbf{7 4 8}$ & $\mathbf{0}$ & $\mathbf{3 0 4}$ & $\mathbf{8 2 0}$ \\
\hline
\end{tabular}


Table 3. Contd, Monthly Number of C of O Received, Processes, Approved and Collected: 2002

\begin{tabular}{|c|c|c|c|c|c|c|c|c|c|}
\hline \multirow[b]{3}{*}{ Month } & \multicolumn{9}{|c|}{ Number of Certificate of Occupancy (C.of O) } \\
\hline & \multicolumn{4}{|c|}{ Received for processing } & \multicolumn{3}{|l|}{ Approved } & \multicolumn{2}{|l|}{ Collected } \\
\hline & $\begin{array}{l}\text { States } \\
\text { land }\end{array}$ & Ratification & $\begin{array}{l}\text { Private } \\
\text { land }\end{array}$ & $\begin{array}{l}\text { State } \\
\text { land }\end{array}$ & ratification & $\begin{array}{l}\text { Private } \\
\text { land }\end{array}$ & $\begin{array}{l}\text { State } \\
\text { land }\end{array}$ & ratification & $\begin{array}{l}\text { Private } \\
\text { land }\end{array}$ \\
\hline Jan & 317 & 38 & 69 & & 96 & 128 & 10 & 97 & 113 \\
\hline Feb & 394 & 58 & 70 & & & & 5 & 42 & 76 \\
\hline Mar. & 440 & 70 & 113 & & 1 & 3 & 6 & 31 & 68 \\
\hline Apr. & 360 & 52 & 72 & & 31 & 84 & 4 & 32 & 332 \\
\hline May. & 237 & 43 & 70 & & 24 & 78 & 6 & 25 & 53 \\
\hline Jun. & 258 & 59 & 81 & & 64 & 227 & & 31 & 49 \\
\hline Jul. & 440 & 71 & 113 & & 8 & 101 & 3 & 33 & 88 \\
\hline Aug. & 321 & 68 & 92 & & & & & 21 & 112 \\
\hline Sept. & 238 & 64 & 89 & & 27 & 98 & & 31 & 104 \\
\hline Oct. & & & 0 & & 44 & 113 & & 34 & 132 \\
\hline Nov. & 443 & 119 & 149 & 300 & 68 & 240 & 106 & & \\
\hline Dec. & 286 & 57 & 95 & & 58 & & 249 & 249 & 251 \\
\hline Total & 3734 & 699 & 1013 & 300 & 421 & 1072 & 389 & 626 & 1078 \\
\hline
\end{tabular}

Table 4. Contd. Monthly Number of C of O Received, Processed, Approved and Collected: 2003

\begin{tabular}{|l|l|l|l|l|l|l|l|l|l|}
\hline \multicolumn{7}{|l|}{ Aumber of Certificate of Occupancy (C.of O) } \\
\hline \multicolumn{2}{|l|}{ Received for processing } & \multicolumn{2}{l|}{ Approved } \\
\hline Month & $\begin{array}{l}\text { States } \\
\text { land }\end{array}$ & Ratification & $\begin{array}{l}\text { Private } \\
\text { land }\end{array}$ & $\begin{array}{l}\text { State } \\
\text { land }\end{array}$ & Ratification & $\begin{array}{l}\text { Private } \\
\text { land }\end{array}$ & $\begin{array}{l}\text { State } \\
\text { land }\end{array}$ & Ratification & $\begin{array}{l}\text { Private } \\
\text { land }\end{array}$ \\
\hline Jan & 317 & 38 & 69 & 267 & 50 & 89 & $\mathbf{1 1}$ & 66 & 147 \\
\hline Feb & 62 & 20 & 7 & 270 & $\mathbf{5 6}$ & 73 & $\mathbf{5}$ & 30 & 93 \\
\hline Mar. & 389 & 58 & 66 & 33 & 59 & 195 & 26 & 25 & 65 \\
\hline Apr. & 300 & 42 & 52 & & & 30 & 3 & 34 & 90 \\
\hline May. & 272 & 56 & 74 & & & & & 21 & 30 \\
\hline Jun. & 298 & 47 & 66 & & & & 5 & 11 & 22 \\
\hline Jul. & 217 & 61 & 73 & & 30 & 130 & 3 & 42 & 21 \\
\hline Aug. & 289 & 53 & 118 & & 149 & 190 & 1 & 25 & 125 \\
\hline Sept. & 399 & 58 & 131 & & 1 & 88 & & 36 & 116 \\
\hline Oct. & 322 & 71 & 119 & & 27 & 50 & & 30 & 85 \\
\hline Nov. & 279 & 47 & 53 & & 38 & 71 & & 35 & 70 \\
\hline Dec. & 4009 & 60 & 114 & & 69 & 184 & & 48 & 108 \\
\hline Total & $\mathbf{3 5 5 3}$ & $\mathbf{6 1 1}$ & $\mathbf{9 4 2}$ & $\mathbf{5 7 0}$ & $\mathbf{4 7 9}$ & $\mathbf{1 1 0 0}$ & $\mathbf{5 4}$ & $\mathbf{4 0 3}$ & $\mathbf{9 7 2}$ \\
\hline
\end{tabular}


Table 5. Monthly Number of C of O Received, Processed, Approved and Collected: 2004

\begin{tabular}{|l|l|l|l|l|l|l|l|l|l|}
\hline \multicolumn{7}{|l|}{ Number of Certificate of Occupancy (C.of O) } \\
\hline \multicolumn{2}{|l|}{ Received for processing } & \multicolumn{2}{l|}{ Approved } \\
\hline Month & $\begin{array}{l}\text { State } \\
\text { land }\end{array}$ & Ratification & $\begin{array}{l}\text { Private } \\
\text { land }\end{array}$ & $\begin{array}{l}\text { State } \\
\text { land }\end{array}$ & Ratification & $\begin{array}{l}\text { Private } \\
\text { land }\end{array}$ & $\begin{array}{l}\text { State } \\
\text { land }\end{array}$ & Ratification & $\begin{array}{l}\text { Private } \\
\text { land }\end{array}$ \\
\hline Jan & 327 & 53 & 63 & & 10 & 20 & 1 & 16 & 85 \\
\hline Feb & 397 & 45 & 73 & & $\mathbf{2}$ & 3 & 0 & 14 & 20 \\
\hline Mar. & 524 & 50 & 93 & & 17 & 200 & 0 & 7 & 77 \\
\hline Apr. & 440 & 38 & 46 & & 8 & 59 & 1 & 34 & 134 \\
\hline May. & 236 & 42 & 58 & & 10 & 136 & 0 & 10 & 109 \\
\hline Jun. & 271 & 53 & 59 & & 36 & 127 & 0 & 16 & 112 \\
\hline Jul. & 301 & 49 & 67 & & 10 & 31 & 1 & 4 & 131 \\
\hline Aug. & 354 & 59 & 67 & & 29 & 106 & 0 & 38 & 70 \\
\hline Sept. & 267 & 67 & 96 & & 15 & 81 & 0 & 30 & 79 \\
\hline Oct. & 215 & 41 & 68 & & 0 & 3 & 0 & 11 & 50 \\
\hline Nov. & 234 & 41 & 108 & & 23 & 98 & 0 & 14 & 67 \\
\hline Dec. & 255 & 66 & 113 & & 42 & 80 & 5 & 47 & 108 \\
\hline Total & $\mathbf{3 8 2 1}$ & $\mathbf{6 0 4}$ & $\mathbf{9 1 1}$ & $\mathbf{0}$ & $\mathbf{2 0 2}$ & $\mathbf{9 4 4}$ & $\mathbf{8}$ & $\mathbf{2 4 1}$ & $\mathbf{1 0 4 2}$ \\
\hline
\end{tabular}

Table 6. Monthly Number of C of O Received, Processed, Approved and Collected: 2005

\begin{tabular}{|l|l|l|l|l|l|l|l|l|l|}
\hline \multicolumn{7}{|l|}{ Number of Certificate of Occupancy (C.of O) } \\
\hline \multicolumn{2}{|l|}{ Received for processing } & \multicolumn{2}{l|}{ Approved } \\
\hline Month & $\begin{array}{l}\text { State } \\
\text { land }\end{array}$ & Ratification & $\begin{array}{l}\text { Private } \\
\text { land }\end{array}$ & $\begin{array}{l}\text { State } \\
\text { land }\end{array}$ & Ratification & $\begin{array}{l}\text { Private } \\
\text { land }\end{array}$ & $\begin{array}{l}\text { State } \\
\text { land }\end{array}$ & Ratification & $\begin{array}{l}\text { Private } \\
\text { land }\end{array}$ \\
\hline Jan & 171 & 37 & 65 & & 23 & 27 & 1 & 14 & 24 \\
\hline Feb & 307 & 33 & 82 & & $\mathbf{6 8}$ & 240 & 0 & 18 & 63 \\
\hline Mar. & 342 & 34 & 86 & & 6 & 14 & 0 & 36 & 75 \\
\hline Apr. & 324 & 40 & 36 & & 0 & 0 & 0 & 20 & 75 \\
\hline May. & 222 & 43 & 58 & & & & 27 & 16 & 38 \\
\hline Jun. & 264 & 26 & 78 & & 71 & 186 & 31 & 32 & 111 \\
\hline Jul. & 231 & 37 & 83 & & & 1 & 7 & 27 & 64 \\
\hline Aug. & 289 & 43 & 116 & & & 2 & 10 & 15 & 39 \\
\hline Sept. & 257 & 33 & 105 & & 81 & 197 & 2 & 39 & 98 \\
\hline Oct. & 332 & 22 & 96 & & 18 & 15 & 1 & 28 & 68 \\
\hline Nov. & 280 & 35 & 62 & & 52 & 108 & & 27 & 63 \\
\hline Dec. & 176 & 41 & 76 & & 32 & 88 & & 13 & 55 \\
\hline Total & $\mathbf{3 1 9 5}$ & $\mathbf{4 2 4}$ & $\mathbf{9 4 3}$ & & $\mathbf{3 5 1}$ & $\mathbf{8 7 8}$ & $\mathbf{7 0}$ & $\mathbf{2 9 5}$ & $\mathbf{7 3 8}$ \\
\hline
\end{tabular}


Table 7. Monthly Analysis of Applications Received, Processed, Approved and Revenue Generated on Land Services, 2006

\begin{tabular}{|c|c|c|c|}
\hline \multirow{2}{*}{ MONTH } & \multicolumn{2}{|c|}{$\begin{array}{l}\text { NUMBER OF APPLICATIONS } \\
\text { APPROVED }\end{array}$} & \multirow{2}{*}{ REVENUE (\#) } \\
\hline & RECEIVED & APP0ROVED & \\
\hline Jan & 144 & 50 & $99,862,421.04$ \\
\hline Feb & 176 & 135 & $83,072,278.22$ \\
\hline Mar. & 317 & 194 & $107,122,647.06$ \\
\hline Apr. & 129 & 74 & $169,825,767.86$ \\
\hline May. & 169 & 112 & $161,576,505.65$ \\
\hline Jun. & 186 & 158 & $158,513,974.50$ \\
\hline Jul. & 214 & 133 & $213,252,407.57$ \\
\hline Aug. & 332 & 128 & $190,378,171.52$ \\
\hline Sept. & 126 & 400 & $206,155,618.97$ \\
\hline Oct. & 301 & 165 & $156,457,310.77$ \\
\hline Nov. & 498 & 187 & $295,232,367.93$ \\
\hline Dec. & 185 & 195 & $176,678,105.54$ \\
\hline Total & 2777 & 1931 & $2,018,127,576.63$ \\
\hline
\end{tabular}

Source: Land Use and Allocation Directorate, Land Bureau 